\title{
THE GEOGRAPHY OF ECONOMIC INEQUALITY: A SPATIAL AND INTERTEMPORAL ANALYSIS OF PUBLIC EXPENDITURE IN GREECE
}

\author{
${ }^{1 *}$ Evgenia Anastasiou, ${ }^{2}$ George Theodossiou \\ ${ }^{1}$ Department of Planning and Regional Development, University of Thessaly, Volos, Greece \\ ${ }^{2}$ Department of Business Administration, University of Thessaly, Larissa, Greece \\ *Corresponding author
}

\begin{abstract}
The era of the crisis in Greece induced serious economic repercussions in public administration and governance. Public expenditure, like all budget figures, has undergone adjustments in compliance with a strict and narrow austerity framework. Taking into account that public expenditures represent an indirect measure of relative welfare as well as regional development, their spatial distribution in the Greek territory highlights regional inequalities.

In the present paper, both an intertemporal and spatial analysis is applied to detect and depict the existence and intensity of regional inequalities in Greece, with the ultimate purpose to examine the hypothesis that in times of recession the forces of convergence are stronger. The analysis period concerns the years 2004-2016 and incorporates a range of profound economic, political and social changes within the country. For the purposes of the research, we applied analytical methods such as descriptive statistics, measures of statistical dispersion and specialized mapping analysis programs and geographical information systems (GIS).
\end{abstract}

Keywords: Economic crisis, Public expenditure, Economic inequality, Greek economy

\section{INTRODUCTION}

Both public debate and the scientific community are concerned with the pursuit of effective fiscal policy resulting in economic growth, stability, and social prosperity. In the past decades is observed a tendency to reduce public spending in most countries. The Greek economy is characterized over time by low economic activity and high public debt, inflation rates, increased government spending and corruption (Richter \& Paparas, 2013). On the occasion of the economic crisis and in the context of economic consolidation, it has undergone several budgetary 


\section{International Journal of Social Science and Economic Research}

ISSN: $2455-8834$

Volume: 05, Issue: 04 "April 2020"

revisions. Among other things, it conducted spending reviews from 2008 to 2016 to improve their efficiency and sustainability.

The aggression of the fiscal adjustment has led the Greek economy to a deeper recession which in turn undermined the government's fiscal consolidation efforts as tax revenue declined while welfare spending increased, especially on unemployment benefits. It should be noted that budgetary adjustments have a significant regional dimension, reducing the potential for development especially in regions of those with specific spatial patterns (Psycharis, 2012).

This paper aims to capture the inequalities in the distribution of public expenditure by the regional services of Greece over a twelve-year analysis period (2004 - 2016). The period of study covers an extremely wide range of economic, social and political developments in Greece. The year 2004, left the imprint of a mega-event in Athens, the Olympic Games. By 2008 there was a long period of economic prosperity, however fragile as it turned out. In 2008 Greece was hit by the financial crisis, but the citizens were not aware of its depth but of its duration. In contrast, in 2013 the financial crisis was in full swing. The majority of the Greek population experienced serious economic, social and systemic difficulties both individually and collectively. Until 2016, the country's growth prospects remain unclear, which explains that the crisis facing the Greek economy is chronic. It is not only about the result of the strong downward trend of the economic cycle, but it is related to structural pathogens and weaknesses related to Greece's structural function (Tsakloglou et al., 2016).

Within the time frame of the analysis, it is attempted to provide reliable findings on regional inequalities in Greece, bearing in mind that regional expenditure is an indirect measure of a region's prosperity and at the same time a means of policymaking.

\section{LITERATURE REVIEW}

Public spending plays an important role in the functioning of the economy and society, as it affects a country's productivity, efficiency, and growth. There is a plethora of determinants explaining the size of public spending in the academic debate, inter alia, demographic trends (Alesina \& Wacziarg, 1998), per capita income (Borcherding, 1985), GDP evolution (Baumol, 1967) and technological change, but also perceptions of the role which the state should play.

One of the major theoretical challenges facing economics is understanding of the relationship between public spending and economic growth (Kolluri \& Wahab, 2007; Shelton, 2007). In other words, it is the public expenditure that leads to economic development (Keynes, 1936; Stiglitz, 1987) or public expenditure is the result of economic development (Wagner, 1958). International literature explicitly addresses theories for both cases. 


\section{International Journal of Social Science and Economic Research}

ISSN: $2455-8834$

Volume: 05, Issue: 04 "April 2020"

According to Wagner (1958), as the economy grows, public-sector activity is increasing relative to that of the private sector. Thus, he hypothesized that the longer the economy develops and the higher the standard of living of the people, the greater the size of the public sector, that is, the greater the proportion of productive resources that will be controlled by public bodies. The basic theory that runs counter to Wagner's law is the Keynes theory according to which causality comes from an exogenous factor, public spending, which is a means of influencing economic growth. Keynes (1936) supported active state intervention in the economy through public spending to avert the economic crisis, or to help the economy emerge from the crisis and promote full employment and equitable distribution of income. In the same way, economists (Singh \& Sahni, 1984) and (Ram, 1986) argue that public spending is a factor in boosting investment productivity and ultimately economic growth. (Stiglitz, 1987) also argues that public spending is a country's driving force for a variety of economic activities such as maintaining public order and securing basic social benefits (such as primary care, housing, national defense, and education). Academic literature has a great range of studies showing the effects of public expenditures on economic growth (see for example (Afonso \& Alegre, 2011; Balaguer-Coll \& Prior, 2009).

Economic analysis is directly linked to the spatial dimension to study the spatial distribution of several phenomena. The relationship between growth and space is of the utmost important issue for national and regional decision-making. It affects the overall functioning of an economic system, as it forms agglomeration economies in certain locations (Polyzos, 2011). Also, the spatial development reflects the relative welfare (Anastasiou et al., 2015) and the prosperity level of a region's population (Polyzos et al., 2013) and consequently the regional inequalities. Concerning public expenditures, the issue of both of their spatial allocation and the share among the different categories of expenditure arise. The first issue highlights the necessity to divide expenditure into subcategories and it depends on the political negotiations (Tsekeris, 2014) whereas the second one explores the criteria based on which public expenditure is distributed in space, among others economic growth, government revenue, trade openness, poverty, public debt, dependency ratio, population, and urbanization (Maluleke, 2017).

Regional inequalities in Greece are highly connected to the spatial allocation of public expenditures over time (Figure 1) (Anastasiou et al., 2015; Anastasiou \& Kalogirou, 2012b, 2012a). The regional problem in Greece lays in two aspects, $50 \%$ of the total population and almost $60 \%$ of total economic activity is concentrated in the main metropolitan regions of Attiki and Thessaloniki (agglomeration effect) (Psycharis et al., 2014) and constitute structural problem, due to the combination of historical, geomorphological, economic and political factors (George Petrakos \& Psycharis, 2016a; Tsekeris, 2014). 
Figure 1: Greece: Government spending as a percent of GDP

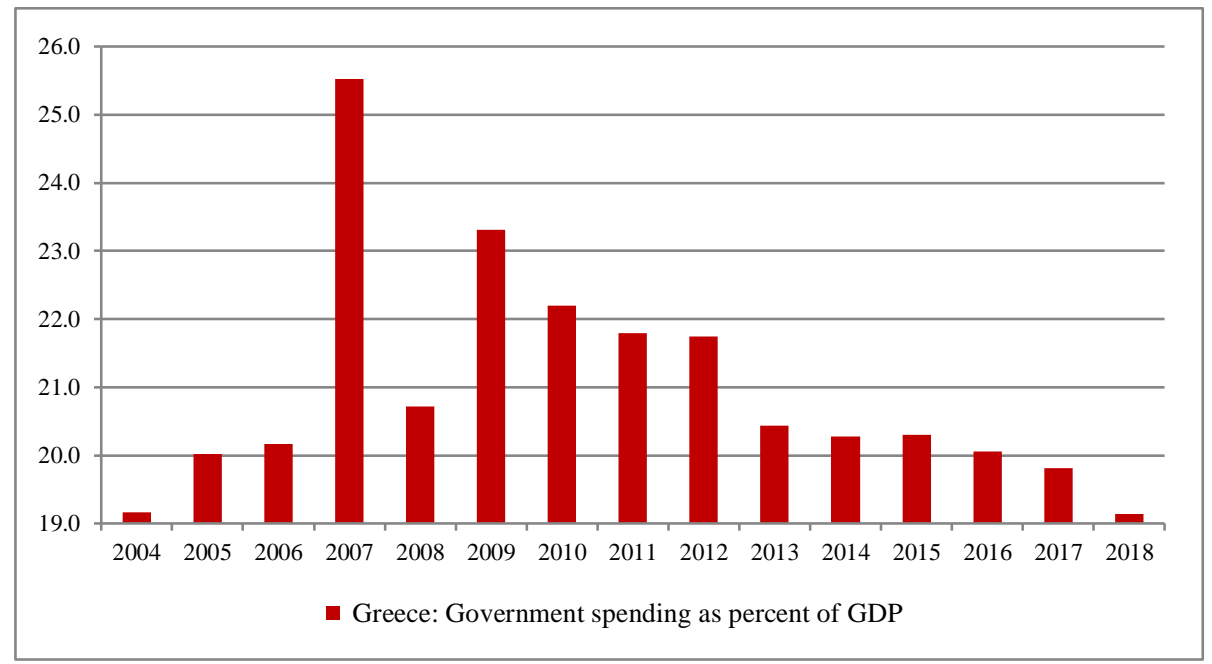

Source: The World Bank, 2019, same compilation

For decades, social and economic development policies have been implemented in the regions of Greece, especially the demographic and economically disadvantaged, in order to achieve a balance within the country, without however having a significant impact on reducing regional disparities. Greece presents fiscal and structural imbalances, rising debt, high deficit and low level of competitiveness (Monastiriotis, 2011). Since 2008 where the economic crisis officially hit the country it is also observed a sharp rise in unemployment rates (both at a regional level and in youth unemployment). The impact of the economic recession left its footprint in all regions of Greece, where within the overall crisis situation, the implementation of regional development policies may be fragmented (Psycharis et al., 2014) mainly due to public investment spending declines (Psycharis, 2012).

In academic literature, there is a theoretical background exploring the relationship between regional inequalities and economic crises. Regional disparities decrease in times of recession and increase in periods of growth (Berry, 1988) and this fact is in line with the effects of agglomeration economies on regional resource allocation (Henderson, 1999; Krugman, 1991). In Greece specifically, empirical studies confirm the above showing a positive relationship between regional inequality and the growth rate of the national product (G. Petrakos et al., 2005; G. Petrakos \& Saratsis, 2000). However recent research shows the opposite relationship, that regional disparities tend to intensify during 2008's economic crisis (George Petrakos \& Psycharis, 2016b). 
At the same time, there is some researchers view gaining increasing importance, that restrictive macroeconomic policy within the eurozone in times of economic crisis leads to chronic structural imbalances that sustain regional inequalities (Goda et al., 2016; Onaran, 2010). The same line of thought addresses the European Commission referring that after a long period of convergence the regional inequalities in peripheries of Europe have started to increase (European Commission, 2013). The regions that seem to be more resilient to the crisis are those with population and economic agglomerations (Capello et al., 2015).

\section{DATA}

The present paper addresses the issue of regional disparities in the allocation of public expenditure both spatially and intertemporal. For a better understanding of the analysis, it is important to describe the data and explain the time frame and the spatial scale of the analysis. The data concern the government expenditures and more specifically they refer to the ministries' regional services. They are derived from the annual Budget Reports by the Ministry of Finance which is published on an annual basis. The public expenditures of the Ministries' Regional Services are a specific expenditure category in the regular State Budget and they concern budget appropriations, payments and unallocated appropriations (Ministry of Finance, 2018). The ministries' regional services are classified into four sub-categories (Finance, Education, Regions, Grants), with several services and departments each (Table 1).

\section{Table 1: Outline of the Ministries' Regional Services}

\begin{tabular}{|c|c|}
\hline \multicolumn{2}{|c|}{ Ministries' Regional Services } \\
\hline Financial Services & $\begin{array}{l}\text { Tax Specialists } \\
\text { Fiscal Audit Customs }\end{array}$ \\
\hline Educational Services & $\begin{array}{l}\text { Elementary Schools } \\
\text { Secondary Education } \\
\text { Educational Centers } \\
\text { Regional Administration of Primary and Secondary } \\
\text { Education } \\
\text { Religious Education }\end{array}$ \\
\hline Regional Services & $\begin{array}{l}\text { Administration and local governments Planning and } \\
\text { Development } \\
\text { Public Works } \\
\text { Environmental and Spatial Planning } \\
\text { Health and Social Solidarity } \\
\text { Forests }\end{array}$ \\
\hline
\end{tabular}




\begin{tabular}{|l|l|}
\hline & Agriculture \\
\hline Grants to the Prefectures & Grants for Health and Social Solidarity \\
& Grants for Educational expenditures \\
& Grants for Agriculture \\
& Other Grants \\
\hline
\end{tabular}

Source: Ministry of Finance, same compilation

Moreover, the expenditures are codified according to the payment type and may concern any of the regional departments (Table 2).

Table 2: Type of Expenditure by category

\begin{tabular}{|l|l|}
\hline $\begin{array}{l}\text { Payments for } \\
\text { Services }\end{array}$ & $\begin{array}{l}\text { Public employees' salaries } \\
\text { Remuneration of staff with other types of work contracts } \\
\text { Additional staff benefits } \\
\text { Payments for staff travel } \\
\text { Payments for other services }\end{array}$ \\
\hline $\begin{array}{l}\text { Purchases of } \\
\text { Goods and } \\
\text { Equipment }\end{array}$ & $\begin{array}{l}\text { Purchases of equipment for services, laboratories, etc. } \\
\text { Purchases of sanitary, pharmaceutical and cleaning materials } \\
\text { Purchases of materials for the maintenance and repair of equipment } \\
\text { and buildings } \\
\text { Purchases of food, clothing, catering, camping, and athletic } \\
\text { equipment. Purchases of fuel and lubricants } \\
\text { Various other purchases } \\
\text { Purchases of capital equipment }\end{array}$ \\
\hline $\begin{array}{l}\text { Transfer } \\
\text { Payments }\end{array}$ & $\begin{array}{l}\text { Grants to public sector legal entities } \\
\text { Income subsidies and other transfer payments } \\
\text { Pending }\end{array}$ \\
\hline Expenditures
\end{tabular}




\begin{tabular}{|l|l|}
$\begin{array}{l}\text { that cannot be } \\
\text { classified in } \\
\text { other categories }\end{array}$ & $\begin{array}{l}\text { classified in any of the above categories. } \\
\text { Payment of obligations from complex transactions. }\end{array}$ \\
\hline
\end{tabular}

Source: Ministry of Finance, (Anastasiou et.al, 2015)

The analysis of the data is focused on the 2004-2016 period; therefore, the dataset includes information on the evolution of ministries' regional services expenditure over 12 years. The findings of the analysis over time will shape regional disparities during a period Greece went through different economic, social and political situations. The spatial scale of the analysis is former Prefectures (Nomoi) (NUTS 3) according to the Kapodistrian administrative system for the classification of regions because it is the lowest administrative level at which data is available.

\section{METHODS}

Inequalities measurement both spatially and intertemporally depend significantly on the expenditure allocation. Public expenditure as a crude number offers almost no information, taking into account that Greek prefectures vary significantly in population distribution. For this reason, the "per capita expenditure" ratio for the years 2004-2016 has been created, based on the estimated population for the years 2004-2016.

$$
\text { per capita Expenditure } e_{i}=\frac{\text { Expenditure }_{i}}{\text { Population }_{i}}
$$

where Expenditure $_{\boldsymbol{i}}$ is the regional public expenditure in the prefecture $i$, Population $_{\boldsymbol{i}}$ is the estimated population in the prefecture $i$, and $i=1,2, \ldots .54$ prefectures (former Kapodistrian prefectures). The "per capita expenditure" is a simple quantitative measurement created to support the analysis and captures the potential distribution of expenditure per capita, allowing for a meaningful comparison between prefectures. However, it does not provide any information as to the actual and qualitative correspondence of expenditure to residents, since the expenditure is a public good and is therefore intended for collective consumption.

The analysis will be focused on measures of dispersion (Interdecile dispersion ratios, Coefficient of Variation and Weighted Coefficient of Variation), the Gini coefficient and the Theil index.

\section{Interdecile Dispersion Ratios}

The deciles of distribution enable calculation of the interdecile ratios, that are systematically used in official reports by international organizations (Eurostat, 2019; OECD, 2019) when 
addressing inequalities that enable comparisons over time and/or across spatial units. Consequently, disparities in government expenditures within Greece can be measured using deciles. The deciles subdivide data into ten equal parts. The ratio D9/D1 evidences the difference between the top and bottom decile of the distribution (INSEE, 2016). In particular, the lowest and highest deciles correspond to $10 \%$ of the Greek prefectures earning the least government expenditures (D1) and to the 10\% earning the most (D9). D9/D5 is calculated as the ratio of $10 \%$ of the highest expenditures of the prefectures to those at the median of the expenditures distribution. Finally, D5/D1 is the ratio of the expenditures of the prefectures at the median of the expenditures distribution to those of the $10 \%$ lowest expenditures. A high interdecile ratio indicates inequality of the distribution, disparities and in parallel a low degree of solidarity and integration (INSEE, 2012), which may lead to sociopolitical impact to consider.

\section{Coefficient Variation and Weighted Coefficient Variation}

The coefficient variation $(\mathrm{CV})$ is a descriptive statistical measure linked to statistical inference (Bendel et al., 1989). The coefficient of variation represents the ratio of the standard deviation of the distribution to the mean and is a useful statistic for comparing the degree of variation from one data set to another, even if the means are drastically different. In the formulation of CV's formula, it is used the standard deviation instead of variation, in order to be comparable to the mean and at the same time to eliminate the unit of measurement (Daniel, 2005). Mathematical notation of the $\mathrm{CV}$ is as follows:

$$
\boldsymbol{C V}=\frac{\sqrt{\frac{\sum_{i=1}^{n}\left(x_{i}-\mu\right)^{2}}{N}}}{\mu}(1)
$$

where $\mathrm{N}$ is the number of Greek prefectures (54), $\boldsymbol{x}_{\boldsymbol{i}}$ is the value of the public expenditures per capita in the prefecture $i$ and $\boldsymbol{\mu}$ is the national mean of public expenditures per capita.

It is known that:

$$
\sigma=\sqrt{\frac{\sum_{i=1}^{N}\left(x_{i}-\mu\right)^{2}}{N}}(2)
$$

where $\sigma$ is the standard deviation, so the above mathematical formula (1) is simplified to the following:

$$
\mathrm{CV}=\sigma / \mu * 100
$$

Taking into consideration formula 3 , it is assumed that all statistical units are regarded as of equal share $(1 / \mathrm{N})$. In the case of examining spatial units though, this assumption seems 
insufficient due to the different territorial sizes in each region. Furthermore, research on inequalities doubts about the validity of coefficient variation due to the lack of proportionality criteria (Sheret, 1984). This issue is resolved by a relative measurement of dispersion, the weighted coefficient variation (wCV), which takes into account the relative population weight $\left(\mathrm{w}_{\mathrm{i}}\right)$ of a spatial unit in the total area under consideration (OECD, 2009):

$$
w_{i}=p_{i} / p
$$

where $\boldsymbol{p}_{\boldsymbol{i}}$ and $\boldsymbol{p}$. are, respectively, the population of region i and country. In the present analysis, $\boldsymbol{w}_{\boldsymbol{i}}$ depicts the population weight of each of the 54 prefectures throughout Greece. The weighted $\mathrm{CV}$ is defined as:

$$
w C V=\frac{1}{\bar{y}}\left\{\sum_{i=1}^{N}\left[\left(y_{i}-\bar{y}\right)^{2} w_{i}\right]\right\}^{1 / 2}
$$

Where $\boldsymbol{y}_{\boldsymbol{i}}$ is per capita public expenditures in region i; $\overline{\boldsymbol{y}}$ is the country's average of per capita public expenditures.

\section{$\underline{\text { Gini }}$}

The Gini coefficient is a measure of statistical dispersion (Gini, 1912, 1921). In the review of academic literature, there is a great range of further mathematical specialization and empirical application (Cowell, 2011). As a measure it has been combined with inequalities in income and prosperity, however, it is being applied in the study of inequalities across various sciences as it allows for interregional and international comparisons, but also enables comparisons to be made over time. Gini can remain independent of both income measurement units and the sample population units. For the purposes of this research work the coefficient is defined as follows:

$$
\operatorname{Gini}=\frac{\frac{1}{N^{2}} \sum_{i=1}^{n} \sum_{j=1}^{n}\left|x_{i}-x_{j}\right|}{2 \mu}
$$

where $\boldsymbol{N}$ is the number of Greek prefectures $\boldsymbol{x}_{\boldsymbol{i}}$, is per capita public expenditures in region i, $\boldsymbol{x}_{\boldsymbol{j}}$ is per capita public expenditures in region $\mathrm{j}$ and $\boldsymbol{\mu}$ the country average of per capita public expenditures.

The values of the coefficient range on a scale from 0 to 1 . When the coefficient gets 0 it expresses the perfect equality, that is, the homogeneity in public expenditures distribution among the Greek prefectures. When the value of the Gini coefficient is equal to the unit, then the perfect inequality is expressed, otherwise the total disparity of per capita public expenditures to the Greek prefectures. 
International Journal of Social Science and Economic Research

ISSN: 2455-8834

Volume: 05, Issue: 04 "April 2020"

\section{Theil}

The Theil index is a statistical function of measuring inequalities, which is primarily based on the entropy theory. The initial purpose of use by Theil was to measure regional disparities in per capita product distribution (Hart, 1970). A general form of the index is as follows:

$$
\text { Theil }=\frac{1}{N} \sum_{i=1}^{N} \frac{y_{i}}{\bar{y}} \ln \left(\frac{y_{i}}{\bar{y}}\right)
$$

where $\mathbf{N}$ is the number of Greek prefectures, $\mathbf{y}_{\mathbf{i}}$ is per capita public expenditures in region i, $\overline{\mathbf{y}}$ is the mean of public expenditures across all prefectures.

The index ranges between 0 and (n). When the index value is 0 then there is perfect equality in the understudy variable. When the value is equal to (n) then the maximum possible inequality is observed. Theil is particularly useful in the analysis of regional disparities because it is characterized by its independence of the sample size.

\section{RESULTS}

The analysis was carried out for the 54 Municipalities of Greece. Before presenting the key findings of the analysis, it is necessary to present basic descriptive statistics on the per capita public expenditures for the 2004-2016 period (Table 1). All variables have a large range of values, where in some cases (2005 and 2006) the maximum value is more than twenty times the minimum value.

The first indications of the crisis were imprinted in 2007 where public spending experienced a particularly declining pace (mean decline 82,9\%), which continued for years to come. All 54 Greek prefectures registered cuts in per capita expenditures higher than $70 \%$. In the majority of prefectures (83\%) in 2008 are observed per capita expenditures between 10 and $30 €$, while it appears that the $\%$ change to the previous year is lightly positive $(12,2 \%)$. Similar situated are the per capita public expenditures in the period 2008-2009 recording 9,7\% mean change. The particularly high expenditures in specific regional units in 2010 significantly increase the country's mean to $35,8 €$ per capita $(31,6 \%$ mean increase to 2009$)$ for the last time until the year 2016. 2011 marks an increasing downward trend concerning 2010 (-66,2\% change) and records mean expenditures per capita $12,1 €$. Until 2015 there is a declining pace $(-16,5 \%,-17,8 \%,-6 \%$, $5,1 \%$ respectively) that reverses in $2016(15,6 \%)$. Nevertheless, the minimum values in per capita expenditure remain at extremely low levels $(3,4 €)$. Throughout the study period the minimum levels of expenditure record low values, while the maximum values show greater fluctuations. 
International Journal of Social Science and Economic Research

ISSN: 2455-8834

Volume: 05, Issue: 04 "April 2020"

Table 3: Descriptive statistics of per capita public expenditures and \% change of per capita public expenditures, 2004-2016

\begin{tabular}{|c|r|r|r|r|r|r|}
\hline $\begin{array}{c}\text { Public Expenditures / } \\
\text { Year }\end{array}$ & Mean & Median & $\begin{array}{c}\text { Std. } \\
\text { Deviation }\end{array}$ & Minimum & Maximum & Range \\
\hline 2004 & 80,9 & 72,4 & 37,6 & 19,2 & 217,4 & 198,1 \\
2005 & 113 & 100,9 & 59,8 & 13,2 & 332,3 & 319,1 \\
2006 & 129,4 & 124,3 & 60,0 & 37,5 & 345,9 & 308,4 \\
2007 & 22,1 & 18,0 & 14,0 & 9,9 & 96,5 & 86,6 \\
2008 & 24,8 & 20,3 & 15,2 & 12,1 & 109,2 & 97,2 \\
2009 & 27,2 & 24,2 & 16,8 & 7,2 & 119,3 & 112,1 \\
2010 & 35,8 & 32,6 & 13,5 & 20,3 & 116,6 & 96,3 \\
2011 & 12,1 & 9,7 & 7,8 & 4,8 & 52,4 & 47,6 \\
2012 & 10,1 & 7,8 & 7,8 & 3,8 & 42,6 & 38,7 \\
2013 & 8,3 & 6,2 & 5,7 & 3,5 & 36,6 & 33,2 \\
2014 & 7,8 & 6,3 & 4,4 & 3,9 & 24,6 & 20,7 \\
2015 & 7,4 & 6,1 & 3,9 & 3,4 & 23,2 & 19,8 \\
2016 & 8,4 & 7,1 & 6,3 & 3,4 & 47,7 & 44,3 \\
\hline change in Public & Mean & Median & Std. & Minimum & Maximum & Range \\
Expenditures / Year & & & Deviation & & & \\
\hline $2004-2005$ & 59,3 & 33,9 & 178,3 & $-72,8$ & 1301,5 & 1374,3 \\
$2005-2006$ & 40,9 & 18,3 & 137,9 & $-88,7$ & 992,4 & 1081,2 \\
$2006-2007$ & $-80,7$ & $-83,1$ & 12,8 & $-96,0$ & $-21,4$ & 74,6 \\
$2007-2008$ & 14,1 & 12,6 & 17,0 & $-47,9$ & 64,1 & 112,0 \\
$2008-2009$ & 11,5 & 12,2 & 15,8 & $-68,7$ & 35,8 & 104,4 \\
$2009-2010$ & 49,1 & 43,4 & 62,1 & $-19,4$ & 447,4 & 466,8 \\
$2010-2011$ & $-65,2$ & $-70,7$ & 23,5 & $-84,8$ & 77,5 & 162,3 \\
$2011-2012$ & $-17,7$ & $-21,8$ & 21,9 & $-54,7$ & 61,7 & 116,4 \\
$2012-2013$ & $-11,9$ & $-13,5$ & 21,2 & $-57,7$ & 41,7 & 99,4 \\
$2013-2014$ & $-1,6$ & 1,2 & 23,7 & $-49,5$ & 99,6 & 149,1 \\
$2014-2015$ & $-0,8$ & $-2,2$ & 18,7 & $-48,3$ & 52,8 & 101,1 \\
$2015-2016$ & 13,3 & 1,6 & 35,7 & $-47,0$ & 105,4 & 152,4 \\
\hline S0ur & & & & \\
\hline
\end{tabular}

Source: same compilation

For the current analysis, it comes that the mean value is not the appropriate measure to show the expenditures central tendency due to the sensitiveness to the outliers. On the contrary, the median throughout the years remains lower than the average value of Greece, indicating that regional units with a low spending intensity significantly and positively affect inequalities. Having regard to the first reading of the descriptive statistics possible uneven distribution of expenditures is implied to the prefectures both aver time and spatially.

Across Greece, it is observed that throughout the study period, the interdecile ratios are particularly high (Figure 2). The D9/D1 dispersion ratio shows a gap between the highest and the lowest spending regions limited from almost 4 times in 2005 to nearly 2 times in 2010. This means that in 2005 the $10 \%$ of the prefectures with the highest government spending consumed 
at least twice as much as the $10 \%$ of the highest spending prefectures in 2010 , while at the same time the $10 \%$ of the prefectures with the lowest government spending consumed at least twice as much as the $10 \%$ of the lowest spending prefectures in 2010. After 2005, 2011 (3.64), 2012 (3.56), 2004 (3.39), 2006 (3.33), 2013 (3.22) and 2014 (3.10) register high disparities. According to the evolution of D9/D1 dispersion ratio over the period 2004-2016, there is a declining trend starting from 2005 that tends to be minimized in 2010, increases sharply in 2011 and continues to decline during the period 2011-2016. The same trend to the D9/D1 ratio follows D9/D5 ratio. The year 2011 depicts a significant rise in the expenditures distribution between the richest (10\%) to $50 \%$ (D5) of the prefectures. As concerns ratio D5/D1 it appears fairly stable throughout the study period, especially after 2007, while the highest disparities are registered in 2004 (2.11) and 2005 (2.08). The interdecile ratios show a significant differentiation in government spending distribution over time that tends to be minimized. However, this general trend should not mask the fact that the inequalities were and still remain at relatively high levels.

Figure 2: Interdecile ratios over time (2004-2016)

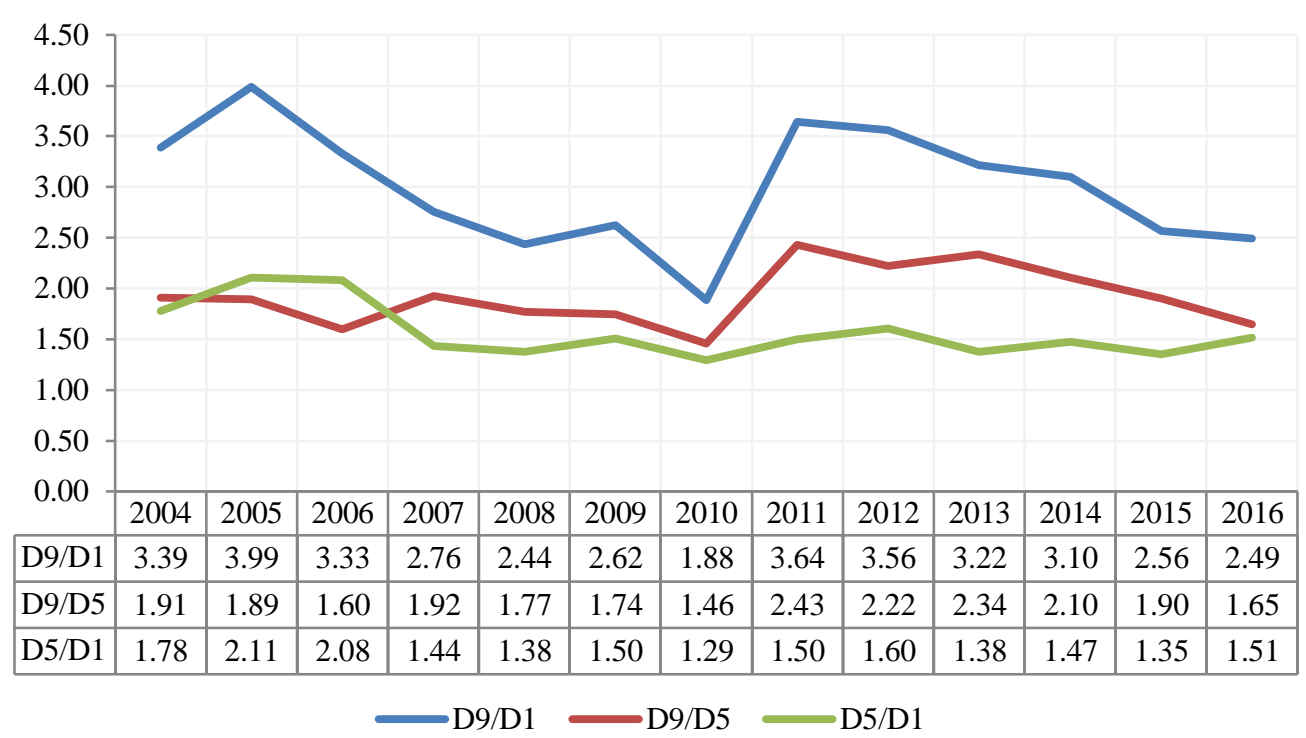

Source: same compilation

The depiction of the percentage change in the distribution of the per capita expenditure (Map 1) offers a more qualitative approach to interpreting the results while highlighting the spatial regional disparities. This illustration presents a comparison of Greece's regional units in four intervals: 2004-2008, 2008-2012, 2012-2016 and 2008-2016. 


\section{International Journal of Social Science and Economic Research}

ISSN: $2455-8834$

Volume: 05, Issue: 04 "April 2020"

The first period of the spatial analysis of expenditure (2004-2008) concerns two opposed time points in Greece. 2004 reflects a country on track for economic growth, whereas 2008 depicts the beginning of the crisis. During this period horizontal cuts were made in the per capita expenditure of regional services in all Greek prefectures. The most favorable prefectures in terms of percentage reduction in expenditure are the island prefectures of Zakynthos (-13.3\%), Lesvos $(-16.3 \%)$, and the Dodecanese $(-26.1 \%) .35 \%$ of prefectures reported a decrease in per capita expenditure of more than $75 \%$. These include the capital of Greece, Athens (-89.9\%) and two major urban centers Larissa (-90.3\%) and Thessaloniki (-85.5\%).

As regards the 2008-2012 period Greece has fully entered a process of budgetary adjustments, and this negative connotation is reflected both in the macroeconomic and socio-demographic indicators. Once again all prefectures show a reduction in per capita expenditures, but of lesser intensity. During this period almost $80 \%$ of the prefectures registered a loss in the per capita expenditures greater than $50 \%$. Only three out of 54 prefectures register reduction over $75 \%$, the Dodecanese (-92.6\%), Pieria $(-77.2 \%)$ and Kilkis $(-77.1 \%)$. The lowest percentage change is recorded in Pireaus (-3.1\%), which is the largest port in Greece, Kavala (-6.1\%) and the island of Corfu (-13.5).

The situation changed in the third interval (2012-2016). This is the first time in the crisis period that prefectures have shown a positive change in the per capita expenditures. More specifically almost $35 \%$ recorded a positive increase in expenditure, $42 \%$ of which registered changes greater than $30 \%$. The highest changes were recorded in two regional prefectures, Messinia (71\%) and Xanthi (70.7\%). Moreover, Piraeus and West Attica recorded positive changes, whereas the extreme cuts in expenditure are limited with the prefecture of Aitoloakarnania registering the highest negative change $(-60 \%)$. Finally, the regions that recorded a modest percentage reduction in their spending $(<15 \%)$ increased by $17 \%$.

The last interval depicts the starting point of the economic crisis (2008) and its maturation (2016). During this period many variations in the per capita expenditure intensities occurred. However, these are not included in the calculation of the percentage change, as it only uses the values of the expenditures at the edges of the period under study (2008 and 2016).

In particular, in the eight years 2008-2016, the majority of prefectures suffered a tremendous loss of per capita regional public expenditure. More than $90 \%$ of regional units have had their spending cut above $50 \%$. Besides, $45 \%$ of regional units reduced their spending by at least $70 \%$. The prefecture of the capital, Athens so as the second-largest greek prefecture, Thessaloniki found to have high levels in cuts in per capita public expenditures over time $(-54.3 \%$ and $-51.5 \%$ respectively). The spatial units that experienced the highest decline in the eight years of the crisis 
are the Dodecanese (-95\%), Lasithi (-81\%), Rethymnon (-81\%) and Pieria (-79\%). The regional units with the least reduction in spending are Arcadia (-30.3\%), Zakynthos (-44.4\%) and Messinia (-47\%). Finally, there is a single spatial unit, Pireaus which in the long run not only did not show a decrease in per capita expenditure but increased by $9 \%$.

Map 1: \% Change in per capita expenditures, 2004-2008, 2008-2012, 2012-2016, 2008-2016
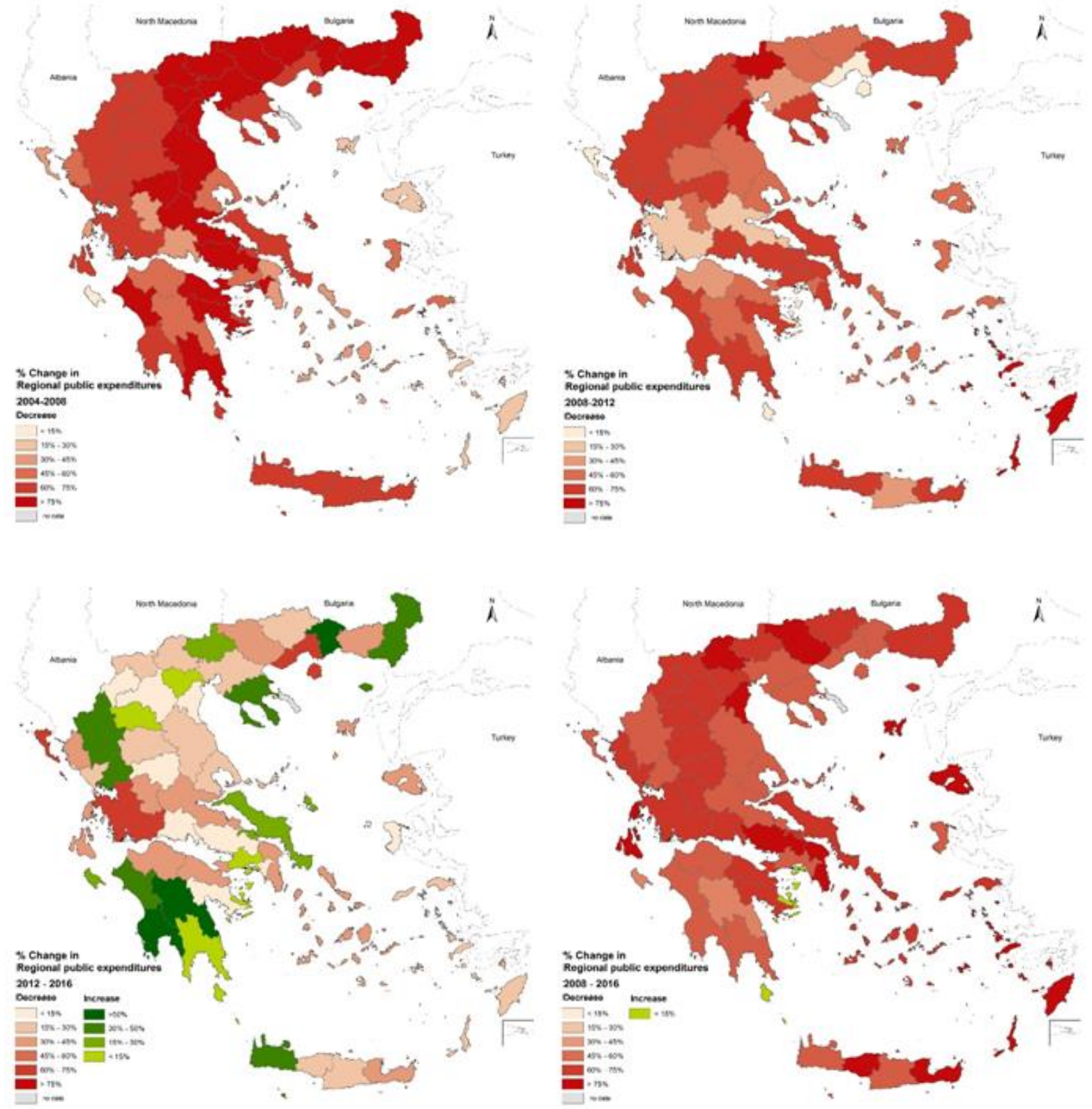

Source: same compilation 
The coefficient of variation and the weighted coefficient of variation (Figure 3) show clearly the inequalities so as to the high fluctuations during the study period (2004-2016). As concerns CV it is obvious that the pre-crisis era shows relatively lower disparities in the public expenditures distribution. The coefficient of variation suggests that government expenditures are more unequally distributed in 2011 (64\%), 2012 (76\%) and 2016 (75\%) conceding that there is a significant disparity in expenditure per capita during the crisis years. The weighted coefficient confirms the high inequalities over time and highlights the magnitude of the problem, as the variation in the data set is huge compared to the average. On this basis, it is derived that with the exception of the year 2011 (58\%) inequalities are sharpening, confirming that the population dynamics of a region have a significant impact on the widening of inequalities. The years 2004 (60\%), 2005 (75\%) and 2006 (93\%) show the greater divergence between the two coefficients (47\%, 54\% and $45 \%$ relatively), where 2010 is observed a significant decline both in CV (37\%) and $\mathrm{wCV}(41 \%)$.

Figure 3: Coefficient of variation and the weighted coefficient of variation, 2004-2016

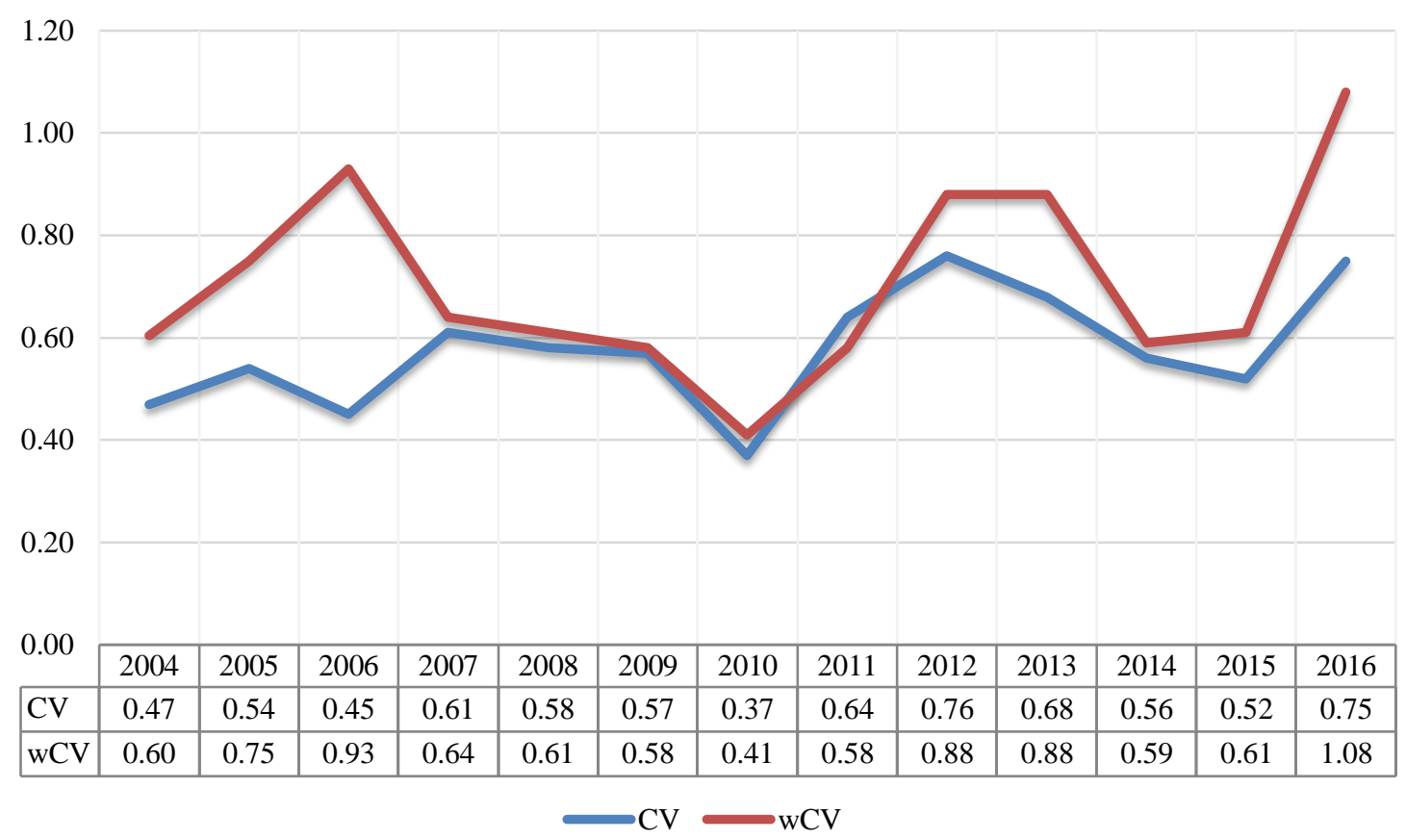

Source: same compilation

The Gini and Theil coefficients used in the present analysis capture the change of the regional services expenditure distribution in Greece over the period 2004-2016 (Figure 4). It is, therefore, possible to consider the variation in regional disparities. Turning to a more detailed analysis, it comes as no surprise that no year has a Gini coefficient close to zero or one, the theoretical limits 
of the measure. Changes in the values of the indicators have been observed over time and consequently, an uneven distribution of the expenditures is observed. For the Gini index, its values range from about 0.17 to 0.33 points. Moderate levels of inequality by international standards (with Gini coefficients around 0.25) are found in most years of the analysis. The lowest levels of inequality are recorded in 2010, a year that compounds the impact and the negative effects of the economic crisis in Greece. 2010 is the most balanced period, as the statistical dispersion of expenditure is relatively homogeneous (0.17), as opposed to the following years (0.3 in 2011 and 2012) where spending is most unevenly distributed in Greece.

The Theil index smoothes out the spatial inequalities, especially in relation to Gini, but still, the imbalance of expenditure is identified relatively high, especially in $2012(0.2), 2013(0.16)$ and 2016 (0.17).

\section{Figure 4: Gini and Theil indexes}

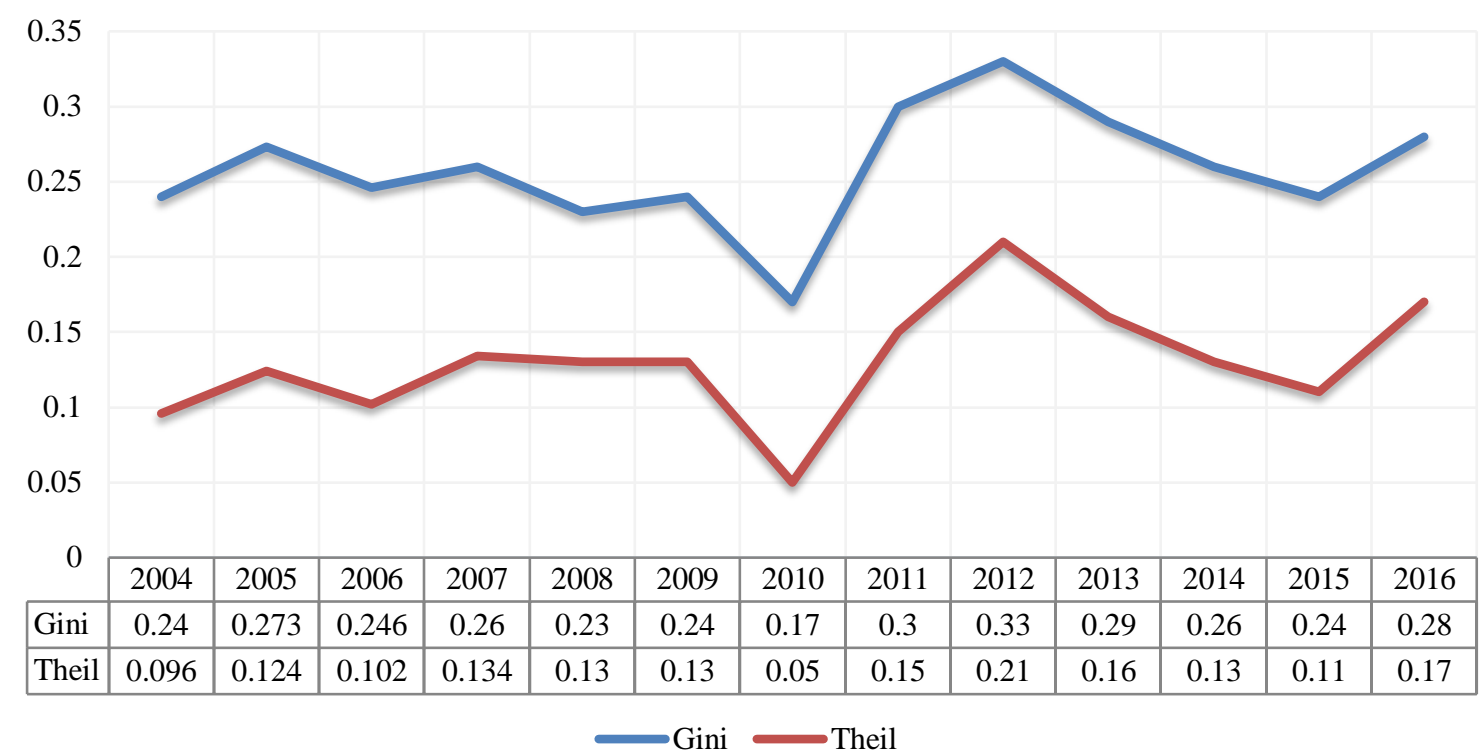

Source: same compilation

\section{DISCUSSION}

The problem of regional disparities has been identified very early and is still one of the major problems of modern economies and societies. The economic crisis has highlighted the internal weaknesses of the public sector, which are largely due to institutional malfunctions and sideeffects of the power wielded by politicians. Both spatial imbalances and social inequalities are therefore inevitable. The role of public expenditure is particularly important in terms of both the 


\section{International Journal of Social Science and Economic Research}

ISSN: $2455-8834$

Volume: 05, Issue: 04 "April 2020"

region's development and the mitigation of regional disparities. Concern has therefore arisen as to whether in the era of the crisis regional inequalities are compounded or not.

Extensive austerity in regional services' public expenditure is highly reflected in the results of the analysis. Consequently, the issue of regional disparities at both the per capita and collective levels is strongly raised. The severe contraction in the amount of public expenditure per capita coincides with the period of recession.

Moderate inequalities are observed in Greece during 2004-2009, but they do not change significantly over time. In 2010, inequalities reach their lowest level in the analysis, leaving scope for a possible convergence. This is, in fact, the first year that the potential implications of the crisis have been felt. In the period 2011-2019, however, the inequality elimination scenarios are disproved, given that the inequality measurement indicators are very high compared to the average of the period under consideration.

From the spatial scope expenditure distribution across regions shows that in the years before the crisis, inequalities were more pronounced than in the crisis era, where again there is relatively uneven distribution, but of less intense, which tends to lead to some degree of convergence. The cross-analysis of time and space reveals a strong imbalance in the change of regional public expenditure in Greek prefectures throughout the study period.

The regional disparities in Greece are significant and constant over time. The inequalities remain strong, especially when measured on a more complex basis than GDP per capita, implying an inability of policymakers to reduce distances and lead to, albeit slow, convergence. Despite the disparities over time, however, there is a particularly significant homogeneity in the distribution of expenditure by year. This is an indication of the harsh horizontal fiscal policy implemented throughout the Greek territory, but at this level limiting spatial inequalities and reaffirming the findings that in times of economic crisis, regional inequalities tend to converge.

\section{REFERENCES}

1. Richter, C., \& Paparas, D. (2013). The Validity of Wagner's Law in Greece during the Last Two Centuries. Applied Economics Quarterly, 59(4), 331-360. https://doi.org/10.3790/aeq.59.4.331

2. Psycharis, Y. (2012). Spatial dimensions of the economic crisis- the geographical print of the crisis in Greece. Region \& Periphery, 1, 117-128 [in Greek]. https://doi.org/10.12681/rp.18531

3. Tsakloglou, P., Oikonomidis, G., Pagoulatos, G., Triantopoulos, X., \& Filippopoulos, A. (2016). A Roadmap to Exit the Crisis: A New Growth Model For Greece | Dianeosis. 


\section{International Journal of Social Science and Economic Research}

ISSN: $2455-8834$

Volume: 05, Issue: 04 "April 2020"

https://www.dianeosis.org/en/2017/03/a-new-production-model/

4. Alesina, A., \& Wacziarg, R. (1998). Openness, Country Size and Government. Journal of Public Economics, 69(3), 305-321. https://doi.org/10.1016/S0047-2727(98)00010-3

5. Borcherding, T. E. (1985). The causes of government expenditure growth: A survey of the U.S. evidence. Journal of Public Economics, 28(3), 359-382. https://doi.org/10.1016/00472727(85)90065-9

6. Baumol, W. J. (1967). Macroeconomics of Unbalanced Growth: The Anatomy of Urban Crisis. In The American Economic Review (Vol. 57, Issue 3).

7. Kolluri, B., \& Wahab, M. (2007). Asymmetries in the conditional relation of government expenditure and economic growth. Applied Economics, 39(18), 2303-2322. https://doi.org/10.1080/00036840600707126

8. Shelton, C. (2007). The size and composition of government expenditure. Journal of Public Economics, 91(11-12), $2230-2260$. https://econpapers.repec.org/RePEc:eee:pubeco:v:91:y:2007:i:11-12:p:2230-2260

9. Keynes, J. M. (1936). The General Theory of Employment, Interest, and Money. Harcourt, Brace \& World Inc. http://etext.library.adelaide.edu.au/k/k44g/k44g.html

10. Stiglitz, J. (1987). Pareto Efficient and Optimal Taxation and the New New Welfare Economics (No. 2189). https://doi.org/10.3386/w2189

11. Wagner, A. (1958). Three Extracts on Public Finance. In R. A. Musgrave \& A. T. Peacock (Eds.), Classics in the Theory of Public Finance (pp. 1-15). Palgrave Macmillan UK. https://doi.org/10.1007/978-1-349-23426-4_1

12. Singh, B., \& Sahni, B. S. (1984). Causality between public expenditure and national Income. The Review of Economics and Statistic, 66, 630-644.

13. Ram, R. (1986). Government size and economic growth. American Economic Review, 76, 191-203.

14. Afonso, A., \& Alegre, J. G. (2011). Economic Growth and Budgetary Components: A Panel Assessment for the EU. Empirical Economics, 41(3), 703-723.

15. Balaguer-Coll, T., \& Prior, D. (2009). SHORT AND LONG-TERM EVALUATION OF EFFICIENCY AND QUALITY. AN APPLICATION TO SPANISH MUNICIPALITIES. Applied Economics, 41(23), 2991-3002.

16. Polyzos, S. (2011). Regional Development. Kritiki Publications [in Greek].

17. Anastasiou, E., Theodossiou, G., \& Thanou, E. (2015). Government spending on regional public services in Greece: Spatial distribution of their evolution before and during the financial crisis. 55th Congress of the European Regional Science Association: "World Renaissance: Changing Roles for People and Places”, 25-28 August 2015, Lisbon, Portugal.

18. Polyzos, S., Tsiotas, D., \& Sdrolias, L. (2013). Evaluating the Differences in the Greek 


\section{International Journal of Social Science and Economic Research}

ISSN: $2455-8834$

Volume: 05, Issue: 04 "April 2020"

Regional Productivity, by Applying Shift-Share analysis. 7th Annual International Conference in Management of International Business and Economic Systems (MIBES), 4356.

19. Tsekeris, T. (2014). Multi-sectoral interdependencies of regional public infrastructure investments. Socio-Economic Planning Sciences. https://doi.org/10.1016/j.seps.2014.06.001

20. Maluleke, G. (2017). The Determinants of Government Expenditure: Analysis of the Empirical Literature from 1995 to 2016 Maluleke. Economica, 13(2), 212-219. http://journals.univ-danubius.ro/index.php/oeconomica/article/view/3850/3993

21. Anastasiou, E., \& Kalogirou, S. (2012a). Spatial Inequalities in Regional Services ministries' spending. 7th Greek National Conference of Geographic Information Systems Association.

22. Anastasiou, E., \& Kalogirou, S. (2012b). The Relation of the of Ministries' Regional Services Expenditures with the Development in Greece. 10th Ordinary Scientific Congress of the Greek Regional Science Association: Financial Crisis and Development and Cohesion Policies.

23. Psycharis, Y., Kallioras, D., \& Pantazis, P. (2014). Economic crisis and regional resilience: detecting the 'geographical footprint' of economic crisis in Greece. Regional Science Policy \& Practice, 6.

24. Petrakos, George, \& Psycharis, Y. (2016a). REGIONAL DEVELOPMENT IN GREECE (2nd ed.). Kritiki.

25. Monastiriotis, V. (2011). Making geographical sense of the Greek austerity measures: compositional effects and long-run implications. Cambridge Journal of Regions, Economy and Society, 4(3), 323-337. https://doi.org/10.1093/cjres/rsr026

26. Berry, B. (1988). Migration Reversals in Perspective: The Long-Wave Evidence. International Regional Science Review, 11(3), 245-251.

27. Henderson, V. (1999). How Urban Concentration affects Economic Growth? (No. 2326).

28. Krugman, P. (1991). Increasing Returns and Economic Geography. Journal of Political Economy, 99, 183-199.

29. Petrakos, G., Rodriguez-Pose, A., \& Rovolis, A. (2005). Growth, Integration and Regional Inequalities in Europe. Environment and Planning A, 37, 1837-1855.

30. Petrakos, G., \& Saratsis, Y. (2000). Regional inequalities in Greece. Papers in Regional Science, 79, 57-74.

31. Petrakos, George, \& Psycharis, Y. (2016b). The spatial aspects of economic crisis in Greece. Cambridge Journal of Regions, Economy and Society, 9(1), 137-152. https://doi.org/10.1093/cjres/rsv028

32. Goda, T., Onaran, Ö., \& Stockhammer, E. (2016). Income inequality and wealth 
International Journal of Social Science and Economic Research

ISSN: $2455-8834$

Volume: 05, Issue: 04 "April 2020"

concentration in the recent crisis. In Greenwich Papers in Political Economy (No. 14690). University of Greenwich, Greenwich Political Economy Research Centre.

33. Onaran, Ö. (2010). Fiscal Crisis in Europe or a Crisis of Distribution? In Working Papers (No. wp226). Political Economy Research Institute, University of Massachusetts at Amherst.

34. European Commission. (2013). The urban and regional dimension of the crisis.

35. Capello, R., Caragliu, A., \& Fratesi, U. (2015). Spatial heterogeneity in the costs of the economic crisis in Europe: are cities sources of regional resilience? Journal of Economic Geography, 15, 951-972.

36. Ministry of Finance. (2018). Budgetary Report 2019.

37. Eurostat. (2019). EU statistics on income and living conditions (EU-SILC) methodologyconcepts and contents Statistics Explained. https://ec.europa.eu/eurostat/statisticsexplained/

38. OECD. (2019). Income inequality. https://doi.org/10.1787/459aa7f1-en

39. INSEE. (2016). Inter-decile ratios.

40. INSEE. (2012). National Sustainable Development Strategy Indicators 2010-2013 2012 Edition Highlights Commissariat général au développement durable. http://www.statistiques.developpement-durable.gouv.fr

41. Bendel, R. B., Higgins, S. S., Teberg, J. E., \& Pyke, D. A. (1989). Comparison of skewness coefficient, coefficient of variation, and Gini coefficient as inequality measures within populations. Oecologia, 78, 394-400. https://doi.org/10.1007/BF00379115

42. Daniel, W. (2005). Biostatistics, a foundation for analysis in the health sciences. Willey Series in Probability and Statistics.

43. Sheret, M. (1984). The Coefficient of Variation: Weighting Considerations. Social Indicators Research, 15, 289-295. https://doi.org/10.2307/27521250

44. OECD (Ed.). (2009). OECD Regions at a Glance 2009. OECD.

45. Gini, C. (1912). Variabilità e mutabilità.

46. Gini, C. (1921). Measurement of Inequality of Incomes. The Economic Journal, 31(121), 124-126. https://doi.org/10.2307/2223319

47. Cowell, F. (2011). Measuring Inequality (3d ed.). Oxford University Press (OUP). https://books.google.gr/books?hl=el\&lr=\&id=eCkUDAAAQBAJ\&oi=fnd\&pg=PR11\&ots= msTW0MEDL5\&sig=Cj-

K_sBcL_znbBUqUexfRcE5oNI\&redir_esc $=\mathrm{y} \# \mathrm{v}=$ onepage \&q\&f=false

48. Hart, P. E. (1970). Entropy and Other Measures of Concentration. Journal of the Royal Statistical Society, 134, 73-85. 